\title{
Life-cycle assessment of China's multi-crystalline silicon photovoltaic modules considering international trade
}

\author{
Dong Yang, Jingru Liu, Jianxin Yang*, Ning Ding \\ State Key Laboratory of Urban and Regional Ecology, Research Center for Eco-Environmental Sciences, Chinese Academy of Sciences, P.O. Box 2871,
} 18 Shuangqing Road, Haidian District, Beijing, 100085, People's Republic of China

\section{A R T I C L E I N F O}

\section{Article history:}

Received 10 October 2014

Received in revised form

15 January 2015

Accepted 1 February 2015

Available online 7 February 2015

\section{Keywords:}

Life-cycle assessment

Photovoltaic modules

CML 2001 method

Global warming potential

Multi-crystalline silicon

\begin{abstract}
A B S T R A C T
We performed a life-cycle environmental assessment of China's multi-crystalline silicon photovoltaic (PV) modules associated with international trade. The study distinguished domestic and imported raw materials for PV modules within the framework of a life-cycle assessment based on traditional processes. Domestic process data were collected from typical PV companies in China and the literature. Imported raw material data were obtained from international trade databases and life-cycle inventory primary databases. The results indicate that it is necessary to consider the international trade of raw materials in life-cycle environmental impacts of PV modules produced in China when considering the shift of environmental impacts between countries associated with international trade of material and products. Multi-crystalline silicon PV production and PV module packaging are important manufacturing processes within the context of environmental impacts of the manufacture of PV modules in China. This assessment also reveals that production of multi-crystalline silicon PV modules in the country has emitted significant amounts of greenhouses gases (GHG). For example, over $2.21 \mathrm{E}+07$ tons of $\mathrm{CO}_{2} \mathrm{eq}$ were emitted in 2010, of which $94 \%$ were from Chinese domestic industries and only $6 \%$ from imported raw materials. Regarding the export of PV modules, $82.4 \%$ of GHG emissions in China were from imports of PV modules by other countries. This result implies that while the export of Chinese PV modules supplied a large amount of clean energy to the world, it also caused significant environmental impacts in China.
\end{abstract}

(C) 2015 Elsevier Ltd. All rights reserved.

\section{Introduction}

The solar power resource is abundant, widely available, and one of the major renewable energy sources with great development potential. The primary solar power technology used worldwide is multi-crystalline silicon photovoltaic (PV) modules, which converts the sun's light directly into electricity (Zhang and He, 2013). As energy shortages and environmental problems become increasingly prominent, PV power has received increasing attention globally.

Owing to the huge demand from international markets, the PV industry in China has developed rapidly and become the most important segment of the global PV industry. China has been the largest PV-manufacturing country since 2007, when it became the largest producer of PV modules in the world, shipping $1088 \mathrm{MW}_{\mathrm{p}}$ of multi-crystalline silicon PV modules in that year. Fig. 1 shows

\footnotetext{
* Corresponding author. Tel./fax: +86 1062849802

E-mail address: yangjx@rcees.ac.cn (J. Yang).
}

China's total production of $10 \mathrm{GW}_{\mathrm{p}}$ in 2010, which accounted for $45 \%$ of the worldwide market of PV modules (Li and Wang, 2011). Approximately $90 \%$ of these modules were exported to Europe and North America (GAC, 2011). In contrast, the Chinese domestic PV market is very small, because there is a lack of incentives to promote domestic PV installations. Multi-crystalline silicon is the most important intermediate product of the PV industry. The production of this silicon in China has also seen steady growth, amounting to $84,000 \mathrm{t}$ in 2011, ranking first in the world (Li, 2011). However, this production has not yet met the demands of the Chinese PV industry, and almost $50 \%$ of multi-crystalline silicon came from imports in 2010 (Table 1).

International trade has played a significant role in development of the Chinese PV industry by providing a mechanism to efficiently allocate raw materials, technology and capital. Most raw materials for that industry (i.e., $50 \%$ of multi-crystalline silicon, $100 \%$ of silver paste, $74 \%$ of ethylene vinyl acetate (EVA), and others) are imported, whereas approximately $90 \%$ of PV modules are exported for use abroad. 


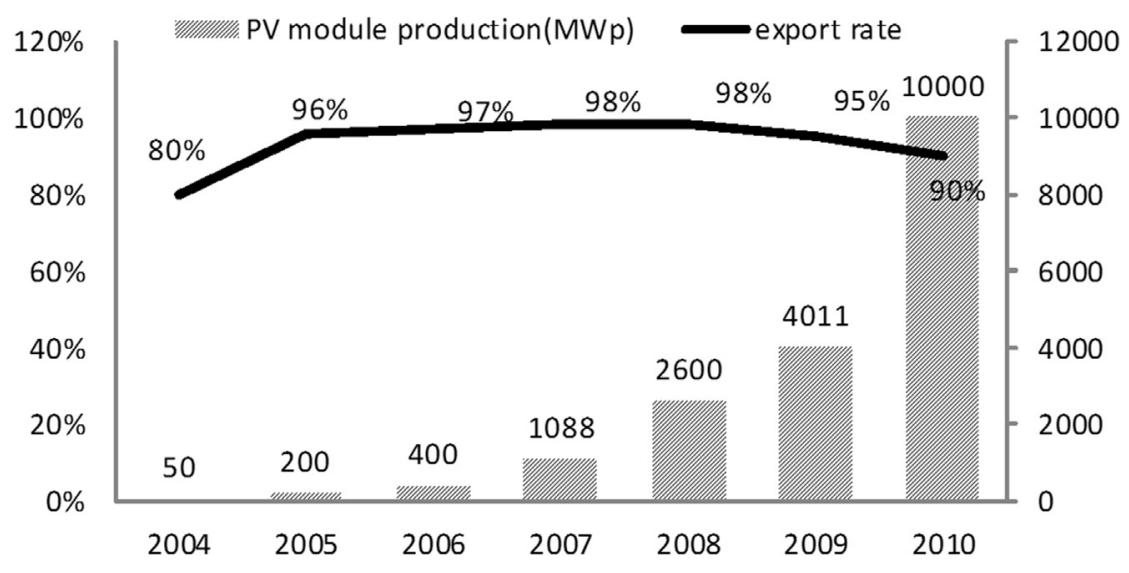

Fig. 1. Production and export rate of PV modules during 2004-2010 in China.

International trade causes a geographic separation between consumers and pollution emitted during the production of consumable items. This provides a mechanism for consumers to shift the environmental pollution associated with their consumption to distant locations (Peters and Hertwich, 2008). Many previous studies have established the pollution embodied in international trade; these are primarily $\mathrm{CO}_{2}$ emissions (Davis and Caldeira, 2010; Yunfeng and Laike, 2010; Peters et al., 2011) but also water pollution (Konar et al., 2011; Payen et al., 2015) and other environmental impacts (Peters and Hertwich, 2006; Bruckner et al., 2012; Cadarso et al., 2012; Steen-Olsen et al., 2012). However, most studies have focused on the environmental impacts and policies of pollution embodied in trade for countries or at a global level. Studies concentrating on specific export industries, such as PV module export, have seldom been published.

International trade causes the separation of consumption and production of PV products. The consumption and production phase of PV modules have different environmental impacts. Among the potential benefits of PV modules in the consumption phase are: 1) production of clean and renewable electrical power, which can meet energy needs (Ito et al., 2008); 2) reduction of greenhouse gas (GHG) emissions, which impacts the global climate (Giacchetta et al., 2013); 3) reduction of pollutant emissions such as nitrogen oxides $\left(\mathrm{NO}_{\mathrm{X}}\right)$, sulfur dioxide $\left(\mathrm{SO}_{2}\right)$, and carbon monoxide $(\mathrm{CO})$, compounds that cause health problems and damage the environment (Bhat and Prakash, 2009); and 4) reduction of toxic emissions, which cause human and ecological harm (Gerbinet et al., 2014). However, the production processes of PV modules can lead to severe pollution and GHG emissions, because the consumption of large amounts of electricity and many types of raw materials is required.

There have been many studies analyzing environmental problems caused by the manufacture of PV products. However, most have focused on EPBT (energy payback time) and specific emissions, especially GHGs. Jungbluth (2005) performed a life-cycle assessment (LCA) for PV power plants using the ecoinvent database. The results indicated an EPBT about 2.5-3 years and a carbon

Table 1

Production and imports of multi-crystalline silicon in China during 2007-2011 source (Li, 2011; CRES, 2011).

\begin{tabular}{lccccc}
\hline Year & 2007 & 2008 & 2009 & 2010 & 2011 \\
\hline Production $\left(10^{4} \mathrm{t}\right)$ & 0.11 & 0.47 & 2.04 & 4.5 & 8.4 \\
Importation $\left(10^{4} \mathrm{t}\right)$ & 1.1 & 1.7 & 2.3 & 4.8 & 6.5 \\
Self-sufficiency rate & $10 \%$ & $20 \%$ & $50 \%$ & $48 \%$ & $56 \%$ \\
\hline
\end{tabular}

footprint of PV power in Switzerland of $79 \mathrm{gCO}_{2-\mathrm{eq}} / \mathrm{kWh}$. Raugei (2007, 2009) researched environmental impacts of various types of PV technologies and their future developmental trends. They found that thin film PV modules had less environmental impacts than traditional multi-crystalline silicon PV modules.

The PV industry has developed rapidly over the past decade, and therefore the material inventory and results of environmental impacts have changed as new technologies have become available. Many studies have shown EBPT of multi-crystalline silicon PV power at 1.5-4.36 years, and GHG emission rates $12-170-\mathrm{g} \mathrm{CO}_{2 \text {-eq/ }}$ kWh (Ito et al., 2010; Nishimura et al., 2010; Sumper et al., 2011; Hsu et al., 2012).

Recently, several reports have summarized and updated these estimates based on the latest technologies, which involve thinner modules and more efficient processes (Şengül and Theis, 2011; Kim et al., 2012; Beylot et al., 2014; Bravi et al., 2011; Parisi et al., 2014). Compared with traditional multi-crystalline silicon PV modules, the thin film module PV system was found to be superior to other silicon-based PV systems with respect to energy return and investment.

Nevertheless, nearly all the aforementioned studies focus on PV modules manufactured in OECD countries. Despite the fact that these countries are leading the research and development of PV technology, the majority of PV modules are manufactured in China. As a developing country, China has a different energy and industry structure, with more lenient environmental restrictions. Therefore, the environmental impacts of PV modules made in the country may vary from those manufactured in OECD countries. All the studies mentioned have ignored the impact of international trade. The PV industry in China is highly internationalized, with a long industrial chain at the global level.

Therefore, to enhance understanding of the environmental consequences of the Chinese PV industry, this paper presents a LCA of the manufacturing of multi-crystalline silicon PV modules in the country, taking into consideration international trade. Then, combining the LCA results with PV module export data, we evaluate the shift of environmental impacts attributable to the export of Chinese multi-crystalline silicon PV modules, based on the bottomup method.

\section{Methodology}

LCA (Life Cycle Assessment) is a tool for analyzing the environmental burdens of products or services at all stages of production, consumption, and end disposal (from 'cradle to grave') (ISO, 2006a, 2006b). 


\subsection{Goal and scope}

This study has two main goals:

1) To assess environmental impacts and identify "hot spots" in the life cycle of multi-crystalline silicon PV module manufacturing in China.

2) To quantify the shift of environmental impacts attributable to the export of Chinese multi-crystalline silicon PV modules.

The system under analysis is the production of the aforementioned modules in China. Therefore, to achieve the goals, $1 \mathrm{~kW}_{\mathrm{p}}$ of multi-crystalline silicon PV modules produced is used as the functional unit (FU).

\subsection{System boundaries}

The international trade of raw materials and products is an important factor that affects development of that industry. Fig. 2 shows that only the PV module packaging phase is limited to the Chinese mainland; all other steps operate at the global level.

According to our objective, only the manufacturing phase of the PV module is considered, because other studies have reported nearly all contributions to environmental impacts from the manufacturing phase (Sherwani and Usmani, 2010; Espinosa et al., 2011; Gallardo et al., 2011; Zhong et al., 2011).

There are emissions during the production of PV modules over the entire process, from silicon ore mining to PV module packaging, which includes energy consumption and consumption of other raw materials. Our study covers the main background processes, including the production of energy, raw materials and transportation.

The life cycle of multi-crystalline silicon PV modules is shown in Fig. 2. The system boundary of the study is "cradle to gate", consisting of the following life-cycle stages:

\subsubsection{Silicon ore mining}

Silicon ore, also known as the raw material of industrial silicon, refers to high-purity silicon rock. China is one of the countries with the richest silicon ore. Industrial explosives are used during mining of the ore. The silicon rocks are transported to industrial silicon factories after being broken down by a mechanical crusher. The main materials and energy consumed for manufacturing $1 \mathrm{~kg}$ of silicon ore are presented in Table 2.

\subsubsection{Industrial silicon production}

Industrial silicon here refers to silicon material of purity $99 \%$. The silicon ore is refined to industrial silicon via the use of carbon in a large arc furnace. Approximately one-third of the world's total output of industrial silicon is produced in China. The export volume in 2011 was $~ 0.7$ million tons (CRES, 2010). Principal materials and energy consumed in the manufacture of $1 \mathrm{~kg}$ of industrial silicon are presented in Table 3.

\subsubsection{Multi-crystalline silicon manufacturing}

Multi-crystalline silicon here refers to that with approximately $6 \mathrm{~N}$ purity, used for solar cell production. This production is the most important intermediate product of the multi-crystalline silicon PV module. In this process, industrial silicon is purified in a furnace by repeated pouring and blowing with chemical materials, until it finally solidifies. There are many different methods to produce multi-crystalline silicon, but the preferred one is the modified Siemens process. This process is frequently used to produce this silicon in China. The process requires consumption of large amounts of electrical power and steam during production. As mentioned earlier, almost half the multi-crystalline silicon required by the Chinese PV industry comes from imports. The principal materials and energy consumed for the production of $1 \mathrm{~kg}$ of multicrystalline silicon are listed in Table 4.

\subsubsection{Multi-crystalline silicon chip cutting}

This is an important process in the production of a PV module because it also requires consumption of a large amount of energy. Multi-crystalline silicon is cut into many silicon chips, each $180-\mu \mathrm{m}$ thick, using a mechanical wire cutter. Relevant data are shown in Table 5.

\subsubsection{PV cell production}

The production of PV cells involves many steps, such as surface preparation, dopant diffusion, junction formation, coating, and others. There are many types of chemical materials and other raw materials consumed during this production, including electric pole printing ribbons, nitrogen, oxygen, and argon. The energy consumed during production is dependent on the use of electricity and natural gas, which is equivalent to $200 \mathrm{kWh} / \mathrm{kW}_{\mathrm{p}}$. The main materials and energy consumed for the manufacture of $1 \mathrm{~kW}_{\mathrm{p}}$ of PV cell production are presented in Table 6 .

\subsubsection{PV module packaging}

In PV packaging, individual cells are interconnected in a series and parallel pattern to produce PV modules. There are $20-40$ cells in one PV module package, which requires the use of other materials, such as low-iron glass, EVA, and aluminum frames. The relevant data are listed in Table 7.

\subsection{PV module manufacturing scenarios}

Almost all other LCA studies on this topic have ignored the characteristics of the highly internationalized Chinese PV industry and have not analyzed the influence of international trade. System boundaries of those studies were often assumed to be domestic, which neglects the use of raw materials from abroad. Raw materials from domestic sources and abroad have differing environmental impacts, so it is important to conduct a life-cycle study that explicitly considers the international trade scenario and uses different life-cycle impact data for processes and materials.

To accurately analyze environmental impacts and the influence of international trade, we assumed three different PV module manufacturing scenarios to perform environmental impact assessment of this industry in China. As shown in Fig. 3, scenario 1 is the baseline LCA of PV modules. All raw materials are assumed to be produced in China, and the influence of international trade of raw materials is ignored. Scenario 2 is another picture of the Chinese PV module industry. Multi-crystalline silicon is a key imported raw material in that industry. According to the market share of multi-crystalline silicon, $52 \%$ of the required multi-crystalline silicon is assumed to be imported in this LCA; other raw materials are assumed to be produced in China. Scenario 3 accounts for the full picture of the Chinese PV module industry. Based on PV industry reports and related literature (GAC, 2011), we determined the market share of all raw materials from various sources that were used in the Chinese PV module industry in 2010 (Table 8).

\subsection{Data source and assumptions}

Data of silicon ore mining, multi-crystalline silicon manufacturing, multi-crystalline silicon chip cutting, and PV module packaging were all acquired from surveys and environmental impact assessment reports from relevant factories in China. 


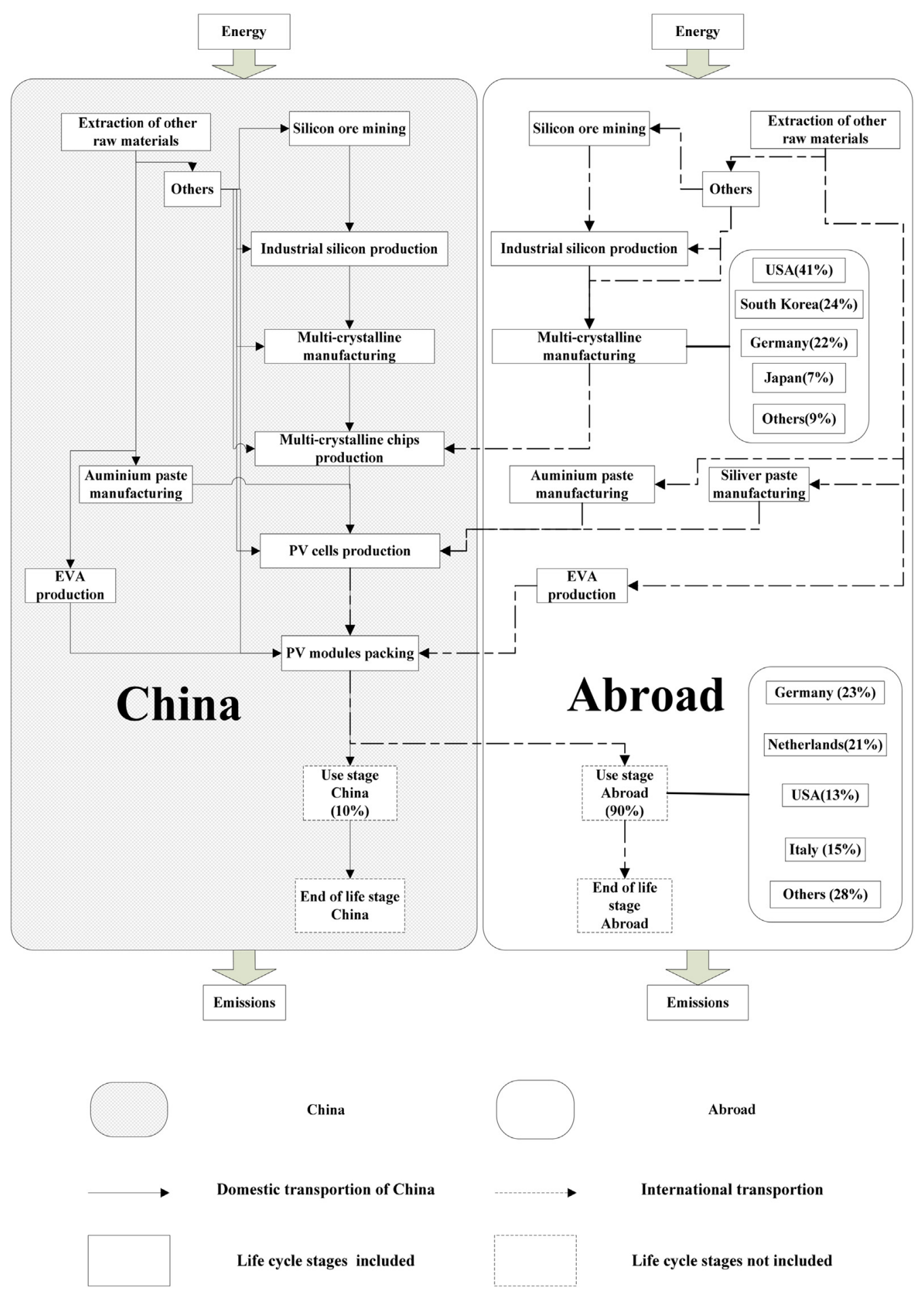

Fig. 2. Geographical allocation and system boundary of the manufacturing of multi-crystalline silicon PV modules in China.

Table 2

Materials and energy consumption data during silicon ore mining.

\begin{tabular}{lll}
\hline Materials & Value & Reference \\
\hline Silicon rocks $(\mathrm{kg} / \mathrm{kg})$ & 1 & Survey of factory \\
Iron $(\mathrm{kg} / \mathrm{kg})$ & 0.0004 & Survey of factory \\
Electricity $(\mathrm{kWh} / \mathrm{kg})$ & 0.07 & Survey of factory \\
\hline
\end{tabular}

Table 3

Materials and energy consumption data during industrial silicon production.

\begin{tabular}{lcl}
\hline Materials & Value & Reference \\
\hline Silicon ore $(\mathrm{kg} / \mathrm{kg})$ & 2.6 & Ye et al. (2007) \\
Charcoal $(\mathrm{kg} / \mathrm{kg})$ & 0.8 & Wu and Jin (2010) \\
Graphite $(\mathrm{kg} / \mathrm{kg})$ & 0.12 & Ye et al. (2007) \\
Water $(\mathrm{kg} / \mathrm{kg})$ & 180 & Ye et al. (2007) \\
Electricity $(\mathrm{kWh} / \mathrm{kg})$ & 13 & Wu and Jin (2010) \\
\hline
\end{tabular}


Table 4

Materials and energy consumption data during multi-crystalline silicon production.

\begin{tabular}{lcl}
\hline Materials & Value & Reference \\
\hline Industrial silicon $(\mathrm{kg} / \mathrm{kg})$ & 1.3 & Survey of factory \\
Chlorine $(\mathrm{kg} / \mathrm{kg})$ & 1.22 & Survey of factory \\
Hydrogen $(\mathrm{kg} / \mathrm{kg})$ & 0.131 & Survey of factory \\
Water $(\mathrm{kg} / \mathrm{kg})$ & 471.2 & Survey of factory \\
Nitrogen $(\mathrm{kg} / \mathrm{kg})$ & 3.876 & Survey of factory \\
Steam $(\mathrm{MJ} / \mathrm{kg})$ & 542 & Survey of factory \\
Electricity $(\mathrm{kWh} / \mathrm{kg})$ & 118 & Survey of factory \\
\hline
\end{tabular}

Data on the industrial silicon manufacturing process were obtained from the literature.

Background life-cycle inventory (LCI) data on upstream and downstream processes, such as the production of energy and chemicals (EVA, silver paste, aluminum paste, and others) and transport of materials, were obtained from the RCEES 2012 database and ecoinvent v2.1 database (Hischier et al., 2010). The RCEES2012 database is the Chinese LCI database, which was developed by the Urban Metabolism and Industrial Ecology research group of the RCEES-CAS (Research Center for EcoEnvironmental Sciences, Chinese Academy of Sciences). Environmental impacts associated with energy consumption in mainland China were obtained from the RCEES 2012 database. LCI data of multi-crystalline silicon and other imported raw materials were directly selected from the ecoinvent v2.1 database, such as silver for producing electrodes, EVA for packaging, and silicon carbide for multi-crystalline silicon cutting. LCI data of raw materials produced in China were obtained from RCEES 2012. We separated transport into domestic and international. Distances assumed for both domestic and international transport were $10,000 \mathrm{~km}$. This distance was assumed based on factory surveys.

\subsection{LCI and LCIA methodology}

SimaPro 7.3 (PRé Consultants, 2011) software was used to organize the inventory data and perform the impact assessment. SimaPro is a popular life-cycle analysis tool that quantitatively measures the environmental impact of a product or service.

We used CML 2001 (Dreyer et al., 2003; Van Oers, 2004) as the characterization method. The calculated impact indicators include global warming potential (GWP, 100 years), abiotic depletion potential (ADP), acidification potential (AP), eutrophication potential (EP), human toxicity potential (HTP), freshwater aquatic ecotoxicity potential (FAEP), marine aquatic ecotoxicity potential (MAEP), terrestrial ecotoxicity potential (TEP), ozone depletion potential (ODP), and photochemical oxidation potential (PCOP).

\section{Results}

\section{1. $L C I$ results}

Table 9 details the main inventory data for the manufacture of $1 \mathrm{~kW}_{\mathrm{p}}$ of multi-crystalline silicon PV modules in China.

From the table, raw material consumption in scenario 1 is greater than those in scenarios 2 and 3, because some of the raw

Table 5

Materials and energy consumption data during multi-crystalline silicon chip cutting.

\begin{tabular}{lcl}
\hline Materials & Value & Reference \\
\hline Multi-crystalline silicon $\left(\mathrm{kg} / \mathrm{kW}_{\mathrm{p}}\right)$ & 7 & Survey of factory \\
Silicon carbide $\left(\mathrm{kg} / \mathrm{kW}_{\mathrm{p}}\right)$ & 19.5 & Survey of factory \\
Electricity $\left(\mathrm{kWh} / \mathrm{kW}_{\mathrm{p}}\right)$ & 118 & Survey of factory \\
\hline
\end{tabular}

Table 6

Materials and energy consumption data during PV cell production.

\begin{tabular}{lcl}
\hline Materials & Value & Reference \\
\hline Multi-crystalline silicon chip $\left(\mathrm{kW}_{\mathrm{p}} / \mathrm{kW}_{\mathrm{p}}\right)$ & 1 & Survey of factory \\
Silver paste $(\mathrm{kg} / \mathrm{kW})$ & 0.09 & Survey of factory \\
Aluminum paste $\left(\mathrm{kg} / \mathrm{kW}_{\mathrm{p}}\right)$ & 0.42 & Survey of factory \\
Electricity $(\mathrm{kWh} / \mathrm{kg})$ & 175 & Survey of factory \\
\hline
\end{tabular}

materials in the latter two scenarios are imported and produced by more advanced and greener production technology. Raw material consumption in scenario 2 is slightly larger than that in scenario 3. This indicates that imported raw material, except for multicrystalline silicon, is not the key contributor to environmental impacts of PV modules in China.

Water was found to be the most used material. Water consumption for $1 \mathrm{kWp}$ in the multi-crystalline silicon PV module manufacturing process is $5.18 \mathrm{E}+04 \mathrm{~kg}$ in scenario $1,3.73 \mathrm{E}+03 \mathrm{~kg}$ in scenario 2 , and $3.68 \mathrm{E}+03 \mathrm{~kg}$ in scenario 3 . The reason for the substantial consumption of water in the manufacturing process is that the level of water recycling is low in China. Silicon ore, silver, aluminum and other metals are principal raw materials in the PV module manufacturing process. The consumption of crude oil and coal corresponds to energy consumed in the process. From Table 9, coal is the dominant energy source in manufacturing, because coal is the most important energy source in China. The difference between the three scenarios indicates that it is necessary to consider the various sources and international trade of raw materials.

Environmental emissions of PV module manufacturing are mainly separated into air emissions, water emissions, and final waste. From Table 9, $\mathrm{CO}_{2}$ and coal ash are the principal atmospheric emissions during the manufacturing process. Multi-crystalline silicon manufacturing is the dominant contributor to environmental emissions in the PV module manufacturing process.

\subsection{LCIA results}

The CML 2001 method was used to estimate environmental impacts. Global warming potential is discussed first, because it is one of the primary worldwide interests related to the environmental impacts of industrial processes. Next, a summary of results for other environmental impacts is presented. Table 10 compares $\mathrm{CML}$ indicators of the various scenarios.

\subsection{LCIA contribution analysis}

To further interpret our results and examine the contributions of different unit processes in each scenario, we analyzed impact contributions. The six main manufacturing processes are silicon ore mining (P1), industrial silicon production (P2), multi-crystalline silicon production (P3), multi-crystalline silicon chip production (P4), PV cell production (P5), and PV module packaging (P6). The indicators are grouped and analyzed below.

Table 7

Materials and energy consumption data during PV module packaging.

\begin{tabular}{lcl}
\hline Materials & Value & Reference \\
\hline Multi-crystalline cell $\left(\mathrm{kW}_{\mathrm{p}} / \mathrm{kW}_{\mathrm{p}}\right)$ & 1.02 & EIA Reports \\
EVA $\left(\mathrm{kg} / \mathrm{kW}_{\mathrm{p}}\right)$ & 8 & EIA Reports \\
Aluminum frame $\left(\mathrm{kg} / \mathrm{kW}_{\mathrm{p}}\right)$ & 21 & EIA Reports \\
Low iron glass $\left(\mathrm{kg} / \mathrm{kW}_{\mathrm{p}}\right)$ & 82 & EIA Reports \\
Corrugated box $\left(\mathrm{kg} / \mathrm{kW}_{\mathrm{p}}\right)$ & 8.75 & EIA Reports \\
Electricity $(\mathrm{kWh} / \mathrm{kg})$ & 25 & EIA Reports \\
\hline
\end{tabular}

EIA Reports: Environmental impacts assessment reports of factory. 

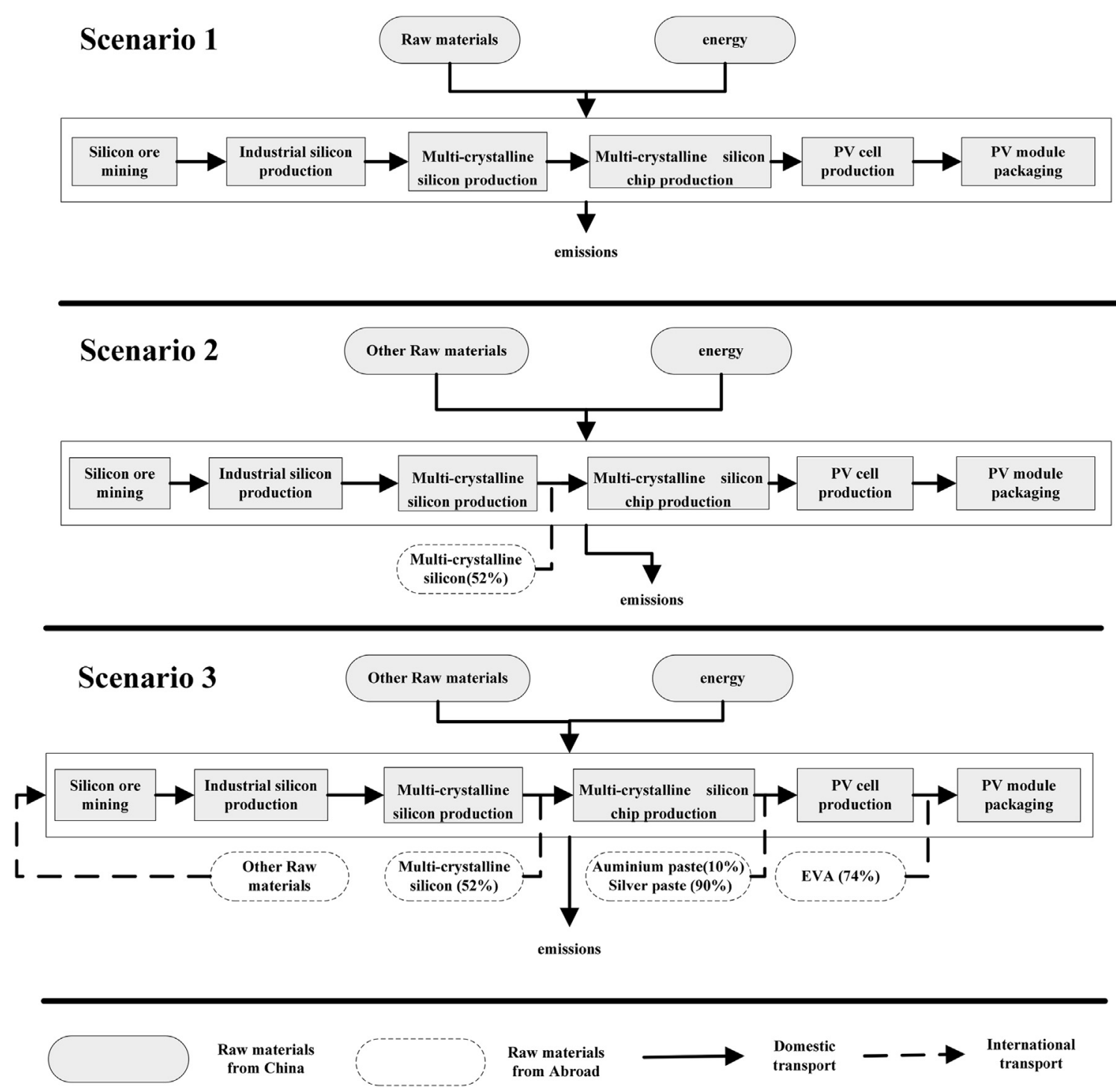

Fig. 3. Different scenarios of PV module manufacturing in China.

Table 8

Market share of raw materials from China and abroad of the Chinese PV module industry in 2010.

\begin{tabular}{lrr}
\hline Raw materials & China & Abroad \\
\hline Silicon ore & $100 \%$ & 0 \\
Iron & $97 \%$ & $3 \%$ \\
Charcoal & $100 \%$ & 0 \\
Graphite & $94 \%$ & $6 \%$ \\
Industrial silicon & $100 \%$ & 0 \\
Chlorine & $100 \%$ & 0 \\
Hydrogen & $100 \%$ & 0 \\
Nitrogen & $100 \%$ & 0 \\
Multi-crystalline silicon & $48 \%$ & $52 \%$ \\
Silicon carbon & $100 \%$ & 0 \\
Multi-crystalline silicon chip & $100 \%$ & 0 \\
Silver paste & 0 & $100 \%$ \\
Aluminum paste & $90 \%$ & $10 \%$ \\
Multi-crystalline silicon cell & $100 \%$ & 0 \\
EVA & $26 \%$ & $74 \%$ \\
Aluminum frame & $99 \%$ & $1 \%$ \\
Low iron glass & $100 \%$ & 0 \\
Corrugated box & $100 \%$ & 0 \\
Water & $100 \%$ & 0 \\
Steam & $100 \%$ & 0 \\
\hline
\end{tabular}

\subsubsection{Global warming potential (GWP, 100 years)}

Characterized GWPs of each $1 \mathrm{~kW}_{\mathrm{p}}$ produced in the PV module manufacturing process (Fig. 4) were $2.91 \mathrm{E}+03-\mathrm{kg} \mathrm{CO}$ eq in scenario $1,2.23 \mathrm{E}+03-\mathrm{kg} \mathrm{CO} \mathrm{CO}_{2} \mathrm{eq}$ in scenario 2 , and $2.21 \mathrm{E}+03-\mathrm{kg} \mathrm{CO}_{2} \mathrm{eq}$ in scenario 3. As observed from Fig. 4, multi-crystalline silicon production (P3) is the "hot spot" of the GWP of the entire process. However, PV module packaging (P6) is also a major contributor to GWP. P3 and P6 respectively account for 52\% and 29\% of GWP in scenario $1,38 \%$ and $38 \%$ in scenario 2 , and $39 \%$ and $38 \%$ in scenario 3 .

From analysis of the GWP contributors, GWP is mainly attributable to the energy consumption of the processes. As mentioned above, consumption of a large amount of electricity and steam is required for the modified Siemens process used in P3. We also found that the dominant factor in P6 is the consumption of aluminum frames. This consumption is associated with frequent use of the electrolytic aluminum method, which consumes a substantial amount of energy in Chinese aluminum production.

GWP of the processes are nearly identical, except for P2 and P3 in scenarios 1 and 2 . This similarity is because the sources of raw materials are nearly the same across scenarios, except for multicrystalline silicon. Approximately 52\% of the demand for this 
Table 9

Inventory data of the manufacturing of $1 \mathrm{~kW}_{\mathrm{p}}$ of multi-crystalline silicon PV modules in China.

\begin{tabular}{|c|c|c|c|c|}
\hline & Unit & Scenario 1 & Scenario 2 & Scenario 3 \\
\hline \multicolumn{5}{|l|}{ Raw } \\
\hline Silicon & $\mathrm{kg}$ & $2.41 \mathrm{E}+01$ & $1.16 \mathrm{E}+01$ & $1.16 \mathrm{E}+01$ \\
\hline Bauxite & $\mathrm{kg}$ & $5.96 \mathrm{E}+01$ & $5.96 \mathrm{E}+01$ & $5.96 \mathrm{E}+01$ \\
\hline Calcite & $\mathrm{kg}$ & $4.77 \mathrm{E}+01$ & $4.62 \mathrm{E}+01$ & $4.62 \mathrm{E}+01$ \\
\hline Coal & $\mathrm{kg}$ & $1.37 \mathrm{E}+03$ & $9.80 \mathrm{E}+02$ & $9.30 \mathrm{E}+02$ \\
\hline Crude oil & $\mathrm{kg}$ & $8.38 \mathrm{E}+01$ & $8.40 \mathrm{E}+01$ & $8.36 \mathrm{E}+01$ \\
\hline Gravel & $\mathrm{kg}$ & $8.97 \mathrm{E}+01$ & $1.02 \mathrm{E}+01$ & $1.02 \mathrm{E}+01$ \\
\hline Iron & $\mathrm{kg}$ & $7.81 \mathrm{E}+01$ & $7.69 \mathrm{E}+01$ & $7.65 \mathrm{E}+01$ \\
\hline Limestone & $\mathrm{kg}$ & $6.21 \mathrm{E}+00$ & $1.26 \mathrm{E}+01$ & $1.21 \mathrm{E}+01$ \\
\hline Natural gas & $\mathrm{kg}$ & $6.99 \mathrm{E}+00$ & $4.20 \mathrm{E}+00$ & $4.18 \mathrm{E}+00$ \\
\hline Sodium chloride & $\mathrm{kg}$ & $2.02 \mathrm{E}+01$ & $2.14 \mathrm{E}+01$ & $2.14 \mathrm{E}+01$ \\
\hline Water & $\mathrm{kg}$ & $5.18 \mathrm{E}+04$ & $3.73 E+04$ & $3.68 \mathrm{E}+04$ \\
\hline Silver & $\mathrm{kg}$ & $1.06 \mathrm{E}-01$ & $1.06 \mathrm{E}-01$ & $1.06 \mathrm{E}-01$ \\
\hline \multicolumn{5}{|l|}{ Final waste } \\
\hline Coal ash & $\mathrm{kg}$ & $1.26 \mathrm{E}+02$ & $1.15 \mathrm{E}+02$ & $1.13 \mathrm{E}+02$ \\
\hline Slags & $\mathrm{kg}$ & $8.10 \mathrm{E}+01$ & $3.16 \mathrm{E}+01$ & $3.15 \mathrm{E}+01$ \\
\hline Industrial waste & $\mathrm{kg}$ & $6.44 \mathrm{E}+01$ & $6.44 \mathrm{E}+01$ & $6.44 \mathrm{E}+01$ \\
\hline \multicolumn{5}{|c|}{ Airborne emissions } \\
\hline $\mathrm{CO}_{2}$ & $\mathrm{~kg}$ & $2.03 E+03$ & $2.00 \mathrm{E}+03$ & $1.99 \mathrm{E}+03$ \\
\hline $\mathrm{CH}_{4}$ & $\mathrm{~kg}$ & $1.04 \mathrm{E}+01$ & $9.79 \mathrm{E}+00$ & $9.78 \mathrm{E}+00$ \\
\hline $\mathrm{NO}_{\mathrm{X}}$ & $\mathrm{kg}$ & $7.29 \mathrm{E}+00$ & $6.85 \mathrm{E}+00$ & $6.85 \mathrm{E}+00$ \\
\hline $\mathrm{SO}_{\mathrm{X}}$ & $\mathrm{kg}$ & $6.44 \mathrm{E}+00$ & $2.03 E+00$ & $1.85 \mathrm{E}+00$ \\
\hline \multicolumn{5}{|c|}{ Waterborne emissions } \\
\hline Sulfate & $\mathrm{kg}$ & $4.62 \mathrm{E}+01$ & $4.26 \mathrm{E}+00$ & $4.26 \mathrm{E}+00$ \\
\hline $\mathrm{BOD}_{5}$ & $\mathrm{~kg}$ & $7.88 \mathrm{E}-01$ & $6.97 \mathrm{E}-01$ & $6.91 \mathrm{E}-01$ \\
\hline COD & $\mathrm{kg}$ & $1.01 \mathrm{E}+00$ & 7.37E-01 & 7.31E-01 \\
\hline Phosphate & $\mathrm{kg}$ & $1.10 \mathrm{E}+00$ & $4.40 \mathrm{E}-01$ & $4.20 \mathrm{E}-01$ \\
\hline
\end{tabular}

Table 10

Environmental impacts of the manufacturing of $1 \mathrm{~kW}$ of PV modules for different scenarios in China.

\begin{tabular}{|c|c|c|c|c|}
\hline & Unit & Scenario 1 & Scenario 2 & Scenario 3 \\
\hline GWP & $\mathrm{kgCO}_{2 \mathrm{eq}}$ & $2.91 \mathrm{E}+03$ & $2.23 \mathrm{E}+03$ & $2.21 \mathrm{E}+03$ \\
\hline ADP & $\mathrm{kgSb}_{\mathrm{eq}}$ & $3.40 \mathrm{E}+00$ & $3.93 \mathrm{E}+00$ & $3.90 \mathrm{E}+00$ \\
\hline $\mathrm{AP}$ & $\mathrm{kgSO}_{2 \mathrm{eq}}$ & $1.76 \mathrm{E}+01$ & $1.33 \mathrm{E}+01$ & $1.33 \mathrm{E}+01$ \\
\hline EP & $\mathrm{kgPO}_{4 \mathrm{eq}}$ & $1.80 \mathrm{E}+00$ & $1.50 \mathrm{E}+00$ & $1.50 \mathrm{E}+00$ \\
\hline HTP & $\mathrm{kg} 1,4 \mathrm{DB}_{\mathrm{eq}}$ & $6.25 \mathrm{E}+01$ & $6.05 \mathrm{E}+01$ & $6.05 \mathrm{E}+01$ \\
\hline FAEP & $\mathrm{kg} 1,4 \mathrm{DB}_{\mathrm{eq}}$ & $1.52 \mathrm{E}+01$ & $1.52 \mathrm{E}+01$ & $1.49 \mathrm{E}+01$ \\
\hline MAEP & $\mathrm{kg} 1,4 \mathrm{DB}_{\mathrm{eq}}$ & $2.69 \mathrm{E}+02$ & $2.69 \mathrm{E}+02$ & $2.64 \mathrm{E}+02$ \\
\hline TETP & $\mathrm{kg} 1,4 \mathrm{DB}_{\mathrm{eq}}$ & 7.10E-02 & $6.36 \mathrm{E}-02$ & $6.28 \mathrm{E}-02$ \\
\hline ODP & $\mathrm{kgCFC}-11_{\mathrm{eq}}$ & $4.51 \mathrm{E}-04$ & $5.72 \mathrm{E}-04$ & $5.80 \mathrm{E}-04$ \\
\hline PCOP & $\mathrm{kgC}_{2} \mathrm{H}_{4 \mathrm{eq}}$ & 6.07E-01 & 4.79E-01 & 4.78E-01 \\
\hline
\end{tabular}

silicon in the Chinese PV industry is met by imports. The environmental impacts and energy consumption of this silicon manufacturing are different for sources in which the technology of imported multi-crystalline silicon is more advanced and greener than that used to produce such silicon in China. The characterized GWP of scenario 1 is greater than that of scenario 2, because imported multi-crystalline silicon manufacturing requires less energy than domestic production.

The GWP of PV module manufacturing in scenario 2 is slightly greater than that in scenario 3 . This shows that imported multicrystalline silicon is the main contributor to the LCA results. However, it is necessary to consider all imported raw materials to obtain a more accurate LCA results for Chinese PV modules.

\subsubsection{Other environmental impacts}

As shown in Table 10, the manufacture of PV modules in scenario 3 reduced impacts for 8 of 10 of the impact factors considered, i.e., AP, EP, GWP, HTP, FAEP, MAEP, TEP, and PCOP. PV module manufacturing in scenario 1 is a better option for the remaining two impacts, ADP and ODP.

By comparing analyses of the environmental impacts of PV modules for different scenarios, we found that PV module manufacturing in scenario 1 contributed to greater environmental impacts than in scenarios 2 and 3. This difference is because raw materials imported from other countries have lower environmental impacts than raw materials produced in China.

Contributions of the impacts are shown in Figs. 5-7. Similar to GWP, the processes of multi-crystalline silicon production (P3) and PV module packaging (P6) are the major "hot spots" for all impacts, except MAEP and FAEP, in which heavy metals are also significant.

Comparing the results of various scenarios, the factor of raw materials trade was found to affect the results. To achieve accurate results, it is necessary to distinguish the source and consider the influence of international trade in the LCA.

\subsection{Environmental impacts of Chinese multi-crystalline silicon PV module industry}

As previously mentioned, almost all PV modules in China are made of multi-crystalline silicon. Therefore, to estimate potential environmental impacts of the PV module industry in the country, our findings were extrapolated to the industry level using a bottom-up approach, which combines the product-based LCA method with the output of PV modules of the Chinese PV industry.

The output of PV module manufacturing in China was $10 \mathrm{GW}_{\mathrm{p}}$ in 2010. Based on results of the full picture of the PV module industry in the country (scenario 3 ), estimated life-cycle environmental impacts are shown in Fig. 8. For example, the Chinese multi-crystalline silicon PV module manufacturing industry was responsible for over $2.21 \mathrm{E}+07$ tons of $\mathrm{CO}_{2} \mathrm{eq}$ emissions in 2010.

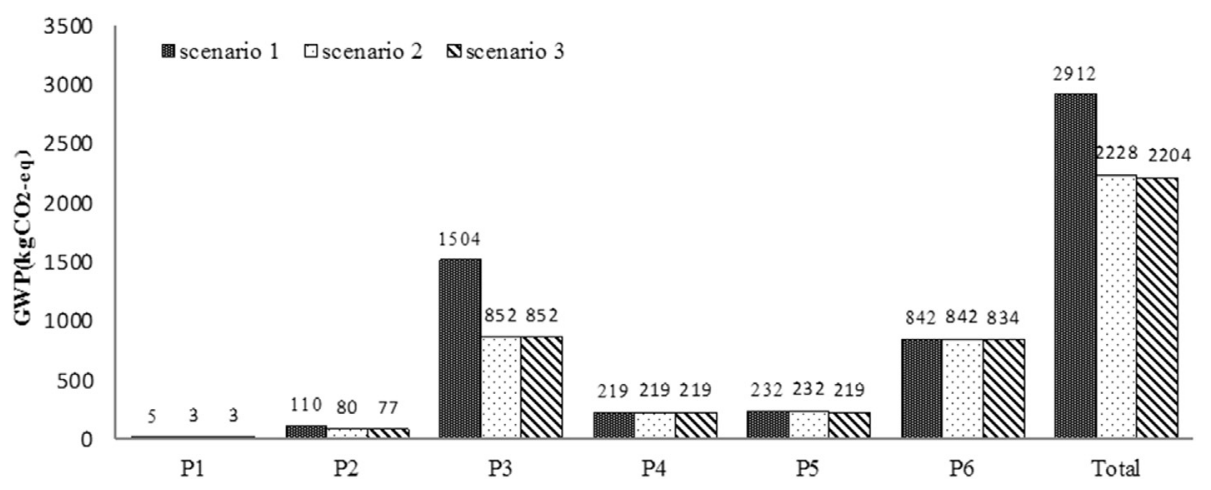

Fig. 4. GWP of $1 \mathrm{~kW}_{\mathrm{p}}$ of PV modules for different manufacturing scenarios showing the contribution of the different processes. 


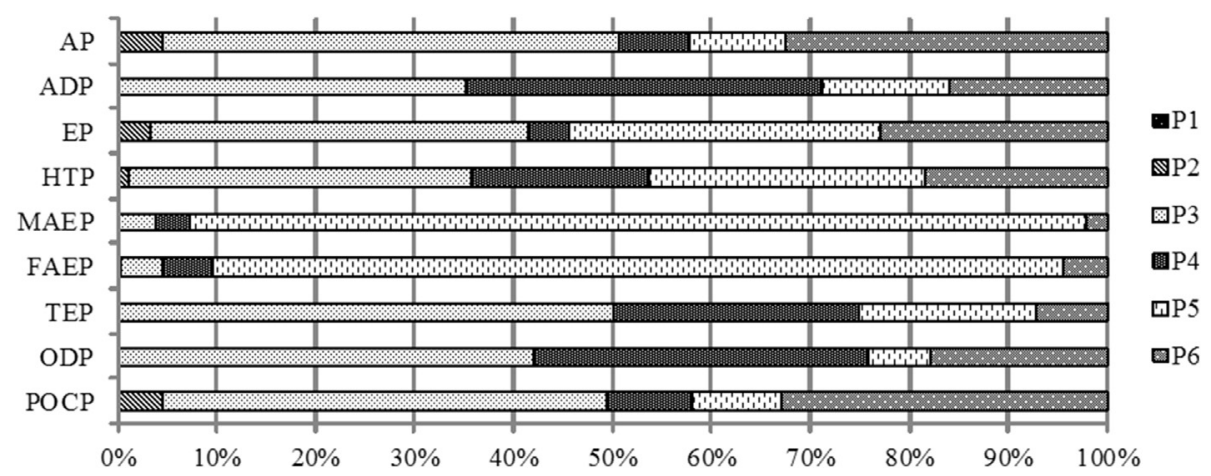

Fig. 5. Contributions of the different processes to the environmental impacts of PV module manufacturing scenario 1.

\subsection{Shift of environmental impacts for exported Chinese PV modules}

As mentioned previously, in 2010, $10 \mathrm{GW}_{\mathrm{P}}$ of PV modules were produced in China, with $90 \%$ of these exported. Based on the export volume of PV modules in that year, we determined the shift of environmental impacts of Chinese PV module export (Fig. 9). We know the portion of raw materials produced abroad. The shift of environmental emissions from Chinese PV module export was divided into emissions from China and abroad. The exports from China were responsible for over $1.99 \mathrm{E}+07$ tons of $\mathrm{CO}_{2}$ eq emissions in 2010 , and $1.82 \mathrm{E}+07$ tons of $\mathrm{CO}_{2}$ eq emissions were from the country. These results indicate that $82.4 \%$ of GHG emissions associated with PV module manufacturing in China were for exports.

Fig. 9 reveals that the shift of environmental impacts from China was greater for 7 of the 10 impacts considered, namely, ADP, AP, EP, GWP, HTP, TEP and ODP. This is because most of the raw materials are from China, which have greater environmental impacts than imported raw materials. The remaining three factors were the main contributors to environmental impacts from abroad, FAEP, MAEP and PCOP. This is attributed to silver paste consumption in the PV manufacturing process, because almost all silver paste required in China comes from imports.

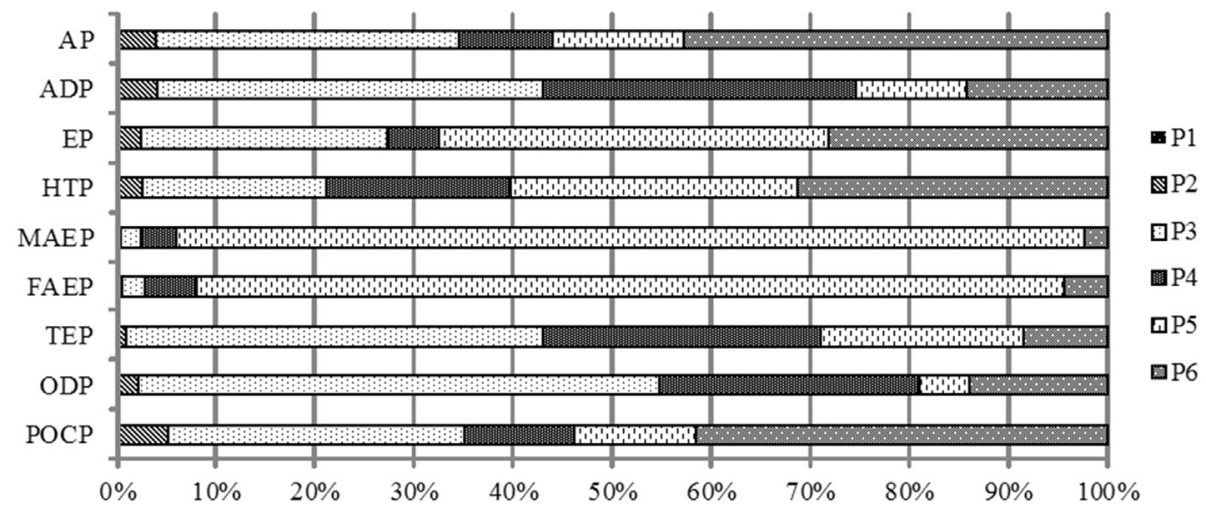

Fig. 6. Contributions of the different processes to the environmental impacts of PV module manufacturing scenario 2 .

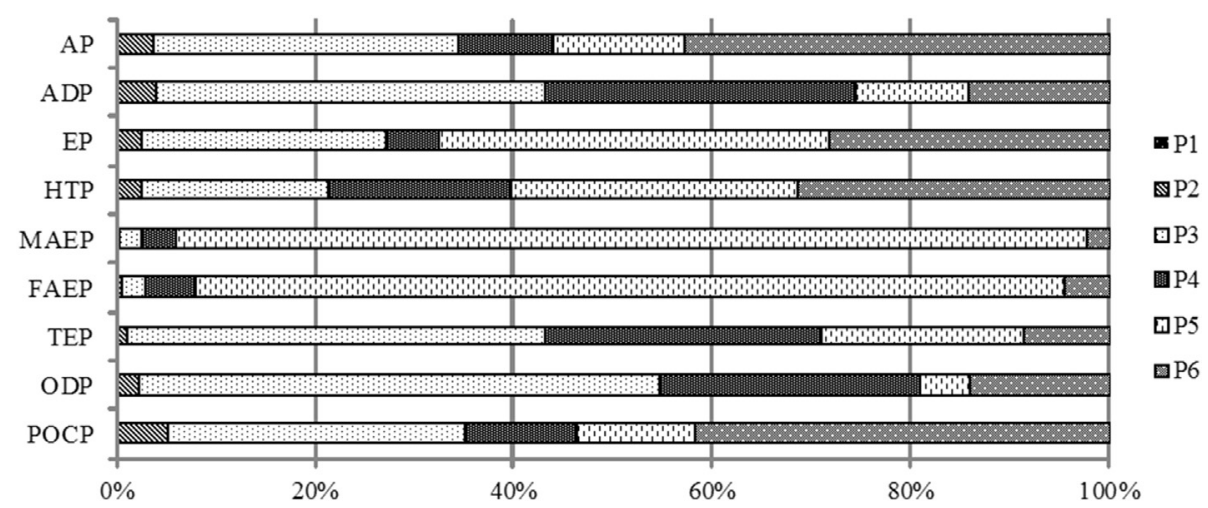

Fig. 7. Contributions of the different processes to the environmental impacts of PV module manufacturing scenario 3. 


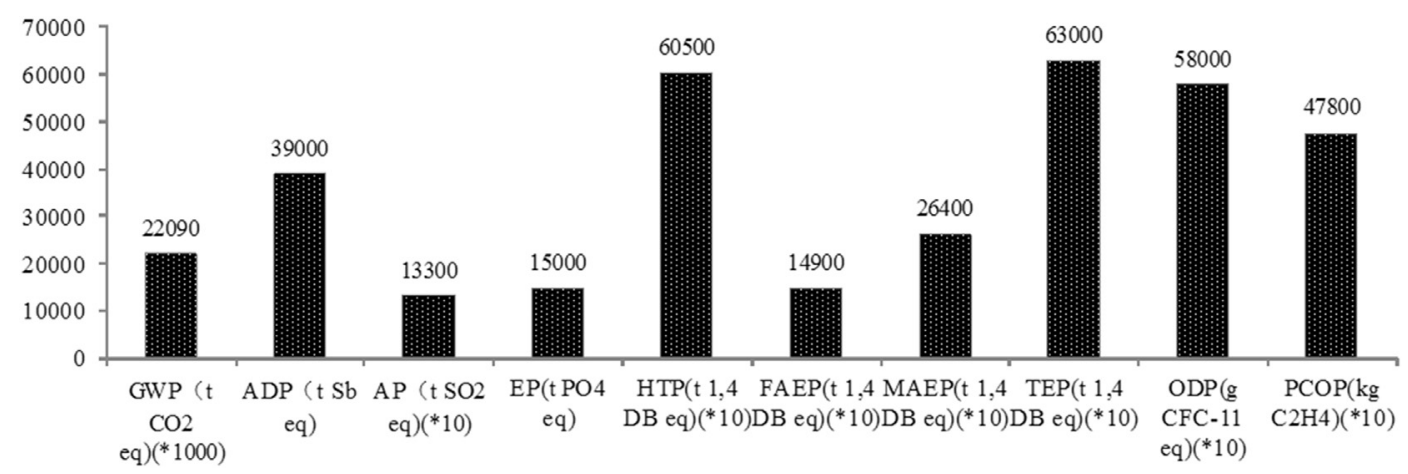

Fig. 8. Contributions of different indictors to the environmental impacts of the PV module industry in 2010.

In summary, exported PV modules supplied a large amount of clean and renewable energy for the world, but also caused significant environmental impacts for China.

\section{Discussion}

\subsection{Comparison of GWP results with those of other studies}

The results for GWP are compared in Fig. 10 to two other Chinese studies of multi-crystalline silicon PV modules (Diao and Shi, 2011; Zhang et al., 2012). Fig. 10-S1, -S2 and -S3 show GWP of producing $1 \mathrm{~kW}$ of multi-crystalline silicon PV modules in different scenarios. Fig. 10-S4 and -S5 are the results of various studies by Diao and Shi. The results of Zhang et al. are $1680-\mathrm{kg} \mathrm{CO} \mathrm{CO}_{2} \mathrm{eq}$ (Fig. 10-S6). Comparing these studies, the results of Diao had the greatest GWP, and those of Zhang et al. the least. Diao's GWP is greater because mainstream technology for producing multi-crystalline silicon PV modules in China was used, and the influence of international trade was neglected. Zhang's result is smaller because many data of secondary raw materials were ignored, and most of the data used were from the literature. The difference of these results was also affected by background energy data and transportation distances. There is currently no national uniform LCI database for China. Most Chinese background LCI data used in research are from the literature and yearbooks. Our results are within the range of Diao's results. It would be helpful to narrow the results and make them more accurate by considering the influence of international trade.

Nevertheless, all the cited studies showed the same trends with respect to multi-crystalline silicon production (P3). Similar to the present study, the investigations of Diao and Zhang indicate that P3 is the main process contributor to GWP and that energy consumption is an important factor in GWP.

\subsection{Sensitivity analysis}

This section presents a sensitivity analysis of environmental impacts for assessing effects on them by various core data, i.e., electricity and steam consumption during domestic P3, market share of imported multi-crystalline silicon in China, and the share of coal burning in the Chinese electricity mix. The analysis was based only on the characteristics of module manufacturing in scenario 3 . The results of the sensitivity analysis are presented in Table 11.

In China, electricity generation by coal burning is important in the electric power industry, accounting for $79 \%$ of the electricity mix. An effective means for reducing the environmental performance of raw materials and energy production is by improving the country's energy mix. A $10 \%$ decrease of coal's share in this mix

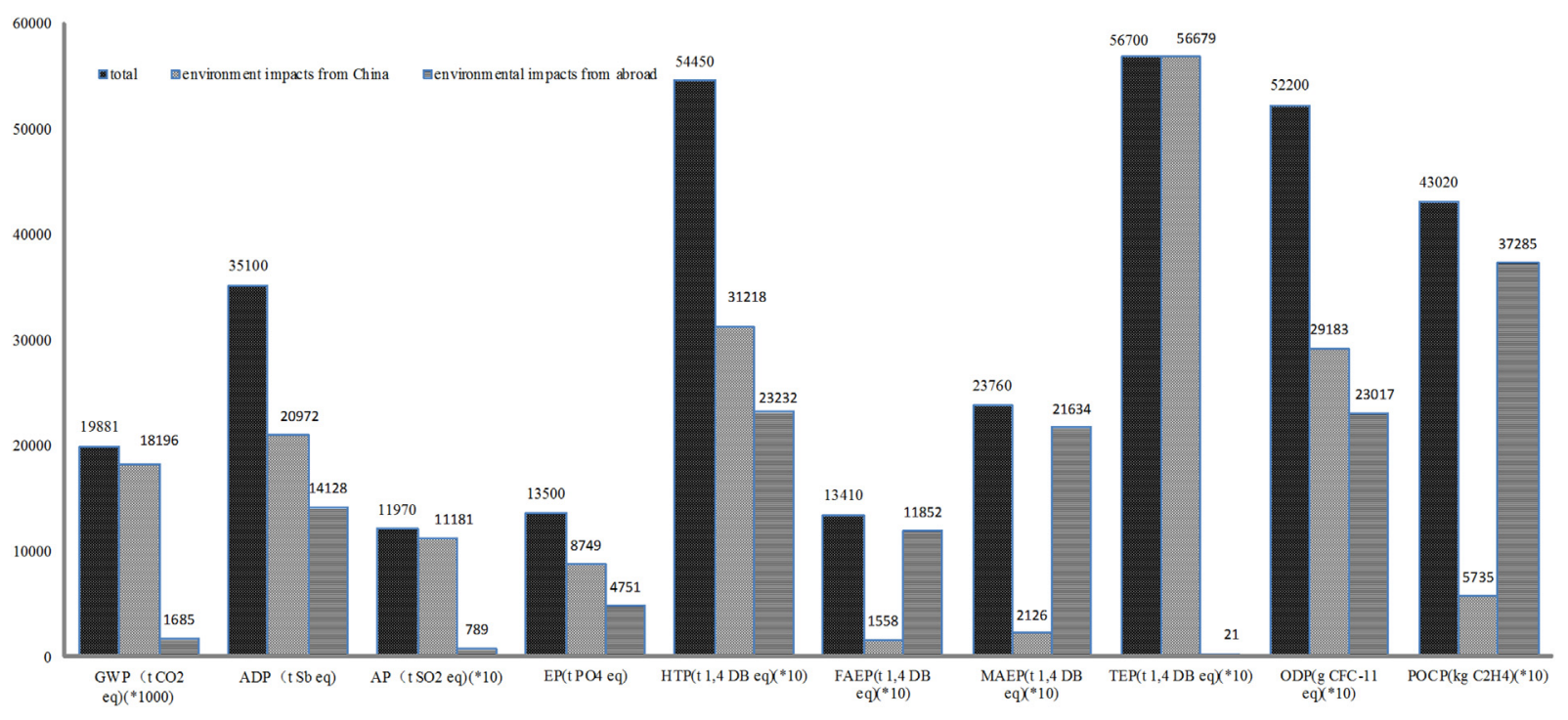

Fig. 9. Exports of PV modules of China and the sources of the shifting environmental impacts in 2010. 


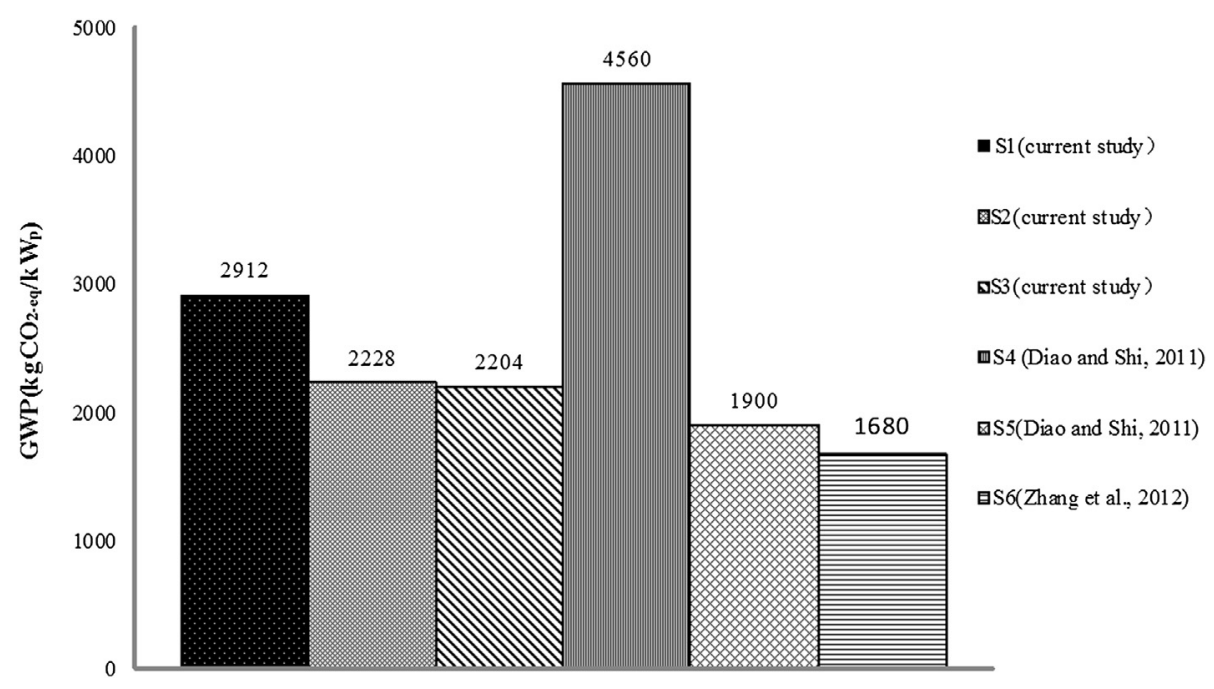

Fig. 10. Comparison of the GWP in the current work with the results of other studies.

would reduce GWP by $8.93 \%$. This factor also had the most influence on AP, EP, HTP, FAEP, and PCOP. The sensitivity analysis indicated that coal burning's share of the national electricity mix is a key influence on the environmental impacts of PV module manufacturing in the country. It is advisable to reduce the environmental load of PV module manufacturing by reducing coal burning to produce electricity in China and by developing renewable and clean electricity production methods.

Market share of imported multi-crystalline silicon in China is also an important factor for the environmental impact indicators. This imported silicon has weaker environmental impacts than the domestic variety. This factor had the strongest effect on ADP, MAEP, TEP and ODP. The factor also had greater influence on other environmental impact indicators. For example, a $10 \%$ increase in the Chinese market share of imported multi-crystalline silicon would reduce GWP by $1.86 \%$. Increasing imports of this silicon would ameliorate the environmental impacts of PV-module manufacturing in the country.

P3 is the "hot spot" contributor to environmental impacts, because the modified Siemens technology consumes substantial energy. Electricity and steam consumption during production of domestic P3 is an important influence on the environmental loads of PV modules. It was found that a $10 \%$ decrease in electricity and steam consumption during production of domestic P3 would cause a $2.14 \%$ total decline of GWP. If the market share of domestic multicrystalline silicon in the country continues to grow, the influence of electricity and steam consumption during P3 will gain importance. The development of new and low-energy-consumption manufacturing technologies for multi-crystalline silicon is necessary to reduce the environmental loads of PV modules.

\section{Conclusions}

The scenario analysis indicates that international trade of raw materials in the life-cycle analysis affected the results. The case study of PV modules indicates that it is necessary to consider international trade in the life-cycle environmental impact assessment of PV modules.

The present study also identifies multi-crystalline silicon production (P3) and PV module packaging (P6) as the main hotspots in the manufacture of Chinese multi-crystalline silicon PV modules, with the greatest environmental impacts. For freshwater and marine aquatic ecotoxicity potentials (FAEP and MAEP), the greatest contributor was PV-cell production (P5).

Our sensitivity analysis indicates that it is important to reduce the environmental load of PV-module manufacturing in the country, by improving the national electricity mix, increasing imports of multicrystalline silicon, and adopting new and low-energy-consumption manufacturing technologies for multi-crystalline silicon.

Analysis at the industrial level revealed that on a life-cycle basis, PV-module manufacturing in China emitted over $2.21 \mathrm{E}+07$ tons of $\mathrm{CO}_{2}$ eq GHG emissions in 2010. PV-module exports from the country were responsible for greater than $1.99 \mathrm{E}+07$ tons of $\mathrm{CO}_{2} \mathrm{eq}$ emissions in that year, and $1.82 \mathrm{E}+07$ tons of $\mathrm{CO}_{2} \mathrm{eq}$ emissions were produced in the manufacture of products for export. Because most of the raw materials for PV module production are from China and the main production processes take place in that country, the major environmental impacts of PV module manufacturing are also in that country. The Chinese PV module export trade has supplied a large amount of clean energy worldwide, but has also had major environmental impacts in the country.

Table 11

Sensitivity analysis for some important parameters.

\begin{tabular}{|c|c|c|c|c|c|c|c|c|c|c|c|}
\hline Parameter & Variation & GWP & ADP & $\mathrm{AP}$ & $\mathrm{EP}$ & HTP & FAEP & MAEP & TEP & ODP & PCOP \\
\hline \multirow[t]{2}{*}{ Domestic electricity consumption in P3 } & $-10 \%$ & $-1.43 \%$ & $0.00 \%$ & $-1.62 \%$ & $-1.45 \%$ & $-0.32 \%$ & $-0.29 \%$ & $0.00 \%$ & $0.00 \%$ & $0.00 \%$ & $-1.72 \%$ \\
\hline & $10 \%$ & $1.43 \%$ & $0.00 \%$ & $1.62 \%$ & $1.45 \%$ & $0.32 \%$ & $0.29 \%$ & $0.00 \%$ & $0.00 \%$ & $0.00 \%$ & $1.72 \%$ \\
\hline \multirow[t]{2}{*}{ Domestic steam consumption in P3 } & $-10 \%$ & $-0.71 \%$ & $0.00 \%$ & $-0.65 \%$ & $-0.72 \%$ & $-0.21 \%$ & $0.00 \%$ & $0.00 \%$ & $0.00 \%$ & $0.00 \%$ & $-0.86 \%$ \\
\hline & $10 \%$ & $0.71 \%$ & $0.00 \%$ & $0.65 \%$ & $0.72 \%$ & $0.21 \%$ & $0.00 \%$ & $0.00 \%$ & $0.00 \%$ & $0.00 \%$ & $0.86 \%$ \\
\hline \multirow[t]{2}{*}{ Market share of imported multi-crystalline silicon } & $-10 \%$ & $1.86 \%$ & $3.61 \%$ & $2.27 \%$ & $2.17 \%$ & $0.00 \%$ & $0.25 \%$ & $0.49 \%$ & $0.76 \%$ & $2.74 \%$ & $2.59 \%$ \\
\hline & $10 \%$ & $-1.86 \%$ & $-3.61 \%$ & $-2.27 \%$ & $-2.17 \%$ & $0.00 \%$ & $-0.25 \%$ & $-0.49 \%$ & $-0.76 \%$ & $-2.74 \%$ & $-2.59 \%$ \\
\hline \multirow[t]{2}{*}{ Coal burning's share of electricity mix in China } & $-10 \%$ & $-8.93 \%$ & $0.00 \%$ & $-10.06 \%$ & $-9.42 \%$ & $-1.82 \%$ & $-0.57 \%$ & $-0.33 \%$ & $0.00 \%$ & $0.00 \%$ & $-8.19 \%$ \\
\hline & $10 \%$ & $8.93 \%$ & $0.00 \%$ & $10.06 \%$ & $9.42 \%$ & $1.82 \%$ & $0.57 \%$ & $0.33 \%$ & $0.00 \%$ & $0.00 \%$ & $8.19 \%$ \\
\hline
\end{tabular}




\section{Acknowledgements}

We acknowledge the support of the 'Strategic Priority Research Program-Climate Change: Carbon Budget and Related Issues' of the Chinese Academy of Sciences (Grant No. XDA05140200).

\section{References}

Beylot, A., Payet, J., Puech, C., Adra, N., Jacquin, P., Blanc, I., Beloin-Saint-Pierre, D., 2014. Environmental impacts of large scale grid connected ground mounted PV installations. Renew. Energy 61, 2-6.

Bhat, I.K., Prakash, R., 2009. LCA of renewable energy for electricity generation systems-A review. Renew. Sustain. Energy Rev. 13 (5), 1067-1073.

Bravi, M., Parisi, M.L., Tiezzi, E., Basosi, R., 2011. Life cycle assessment of a micromorph photovoltaic system. Energy 36 (7), 4297-4306.

Bruckner, M., Giljum, S., Lutz, C., Wiebe, K.S., 2012. Materials embodied in international trade-Global material extraction and consumption between 1995 and 2005. Glob. Environ. Change 22 (3), 568-576.

Cadarso, M.Á.. López, L.A., Gómez, N., Tobarra, M.Á., 2012. International trade and shared environmental responsibility by sector. An application to the Spanish economy. Ecol. Econ. 83, 221-235.

Consultants, P., 2011. SimaPro 7. Pré-Product Ecology Consultants, The Netherlands.

CRES, 2010. China New and Renewable Energy Yearbook 2010 (in Chinese). China Renewable and New Energy Industrial Association, Beijing.

CRES, 2011. China New and Renewable Energy Yearbook 2011 (in Chinese). China Renewable and New Energy Industrial Association, Beijing.

Davis, S.J., Caldeira, K., 2010. Consumption-based accounting of $\mathrm{CO}_{2}$ emissions. Proc. Natl. Acad. Sci. 107 (12), 5687-5692.

Diao, Z.W., Shi, L., 2011. Life cycle assessment of photovoltaic panels in China. Res. Environ. Sci. (in Chinese) 24 (5), 571-579.

Dreyer, L.C., Niemann, A.L., Hauschild, M.Z., 2003. Comparison of three different LCIA methods: EDIP97, CML2001 and eco-indicator 99. Int. J. Life Cycle Assess. 8 (4), 191-200.

Espinosa, N., Garcia-Valverde, R., Krebs, F.C., 2011. Life-cycle analysis of product integrated polymer solar cells. Energ. Environ. Sci. 4 (5), 1547-1557.

GAC, 2011. China Customs Statistics 2010 (In Chinese). China Customs Press, Beijing.

Gallardo, J.R.P., Astier, S., Azzaro-Pantel, C., Pibouleau, L., Domenech, S., 2011. Multiobjective optimization of large scale photovoltaic (PV) systems design: technico-economic and life-cycle assessment considerations. Chem. Eng. Trans. 25, 483-488. http://dx.doi.org/10.3303/Cet1125081.

Gerbinet, S., Belboom, S., Léonard, A., 2014. Life Cycle Analysis (LCA) of photovoltaic panels: a review. Renew. Sustain. Energy Rev. 38, 747-753.

Giacchetta, G., Leporini, M., Marchetti, B., 2013. Evaluation of the environmenta benefits of new high value process for the management of the end of life of thin film photovoltaic modules. J. Clean. Prod. 51, 214-224.

Hischier, R., Weidema, B., Althaus, H.-J., Bauer, C., Doka, G., Dones, R. Frischknecht, R., Hellweg, S., Humbert, S., Jungbluth, N., 2010. Implementation of Life Cycle Impact Assessment Methods. Ecoinvent report.

Hsu, D.D., O'Donoughue, P., Fthenakis, V., Heath, G.A., Kim, H.C., Sawyer, P., Turney, D.E., 2012. Life cycle greenhouse gas emissions of crystalline silicon photovoltaic electricity generation. J. Ind. Ecol. 16 (s1), S122-S135.

ISO, I, 2006a. 14040: Environmental Management-Life Cycle Assessment-Principles and Framework. British Standards Institution, London.

ISO, I, 2006b. 14044:2006 (2006): Environmental Management - Life Cycle Assessment - Requirements and Guidelines. International Standard Organisation, Geneva, Switzerland.

Ito, M., Kato, K., Komoto, K., Kichimi, T., Kurokawa, K., 2008. A comparative study on cost and life-cycle analysis for $100 \mathrm{MW}$ very large-scale PV (VLS-PV) systems in deserts using m-Si, a-Si, CdTe, and CIS modules. Prog. Photovolt. 16 (1), 17-30. http://dx.doi.org/10.1002/Pip.770.

Ito, M., Komoto, K., Kurokawa, K., 2010. Life-cycle analyses of very-large scale PV systems using six types of PV modules. Curr. Appl. Phys. 10 (2) $271-273$.
Jungbluth, N., 2005. Life cycle assessment of crystalline photovoltaics in the swiss ecoinvent database. Prog. Photovolt. 13 (5), 429-446. http://dx.doi.org/10.1002/ Pip.614.

Kim, H.C., Fthenakis, V., Choi, J.K., Turney, D.E., 2012. Life cycle greenhouse gas emissions of thin-film photovoltaic electricity generation. J. Ind. Ecol. 16 (s1), S110-S121.

Konar, M., Dalin, C., Suweis, S., Hanasaki, N., Rinaldo, A., Rodriguez-Iturbe, I., 2011. Water for food: the global virtual water trade network. Water Resour. Res. 47 (5).

Li, J., 2011. China Wind Power Outlook 2011(in Chinese). China Environmental Science Press, Beijing.

Li, J., Wang, S., 2011. China Solar PV Outlook 2011(in Chinese). China Environmental Science Press, Beijing.

Nishimura, A., Hayashi, Y., Tanaka, K., Hirota, M., Kato, S., Ito, M., Araki, K., Hu, E.J., 2010. Life cycle assessment and evaluation of energy payback time on highconcentration photovoltaic power generation system. Appl. Energy 87 (9), 2797-2807. http://dx.doi.org/10.1016/j.apenergy.2009.08.011.

Parisi, M.L., Maranghi, S., Basosi, R., 2014. The evolution of the dye sensitized solar cells from Grätzel prototype to up-scaled solar applications: a life cycle assessment approach. Renew. Sustain. Energy Rev. 39, 124-138.

Payen, S., Basset-Mens, C., Perret, S., 2015. LCA of local and imported tomato: an energy and water trade-off. J. Clean. Prod. 87, 139-148.

Peters, G.P., Hertwich, E.G., 2006. Pollutionembodiedintrade:theNorwegiancase. Glob. Environ. Change 16, 379-387.

Peters, G.P., Hertwich, E.G., 2008. $\mathrm{CO}_{2}$ embodied in international trade with implications for global climate policy. Environ. Sci. Technol. 42 (5), 1401-1407.

Peters, G.P., Minx, J.C., Weber, C.L., Edenhofer, O., 2011. Growth in emission transfers via international trade from 1990 to 2008. Proc. Natl. Acad. Sci. 108 (21), 8903-8908.

Raugei, M., Frankl, P., 2009. Life cycle impacts and costs of photovoltaic systems: current state of the art and future outlooks. Energy 34 (3), 392-399.

Raugei, M., Bargigli, S., Ulgiati, S., 2007. Life cycle assessment and energy pay-back time of advanced photovoltaic modules: CdTe and CIS compared to poly-Si. Energy 32 (8), 1310-1318.

Şengül, H., Theis, T.L., 2011. An environmental impact assessment of quantum dot photovoltaics (QDPV) from raw material acquisition through use. J. Clean. Prod. 19 (1), 21-31.

Sherwani, A.F., Usmani, J.A., 2010. Life cycle assessment of solar PV based electricity generation systems: a review. Renew. Sustain. Energy Rev. 14 (1), 540-544.

Steen-Olsen, K., Weinzettel, J., Cranston, G., Ercin, A.E., Hertwich, E.G., 2012. Carbon, land, and water footprint accounts for the European Union: consumption, production, and displacements through international trade. Environ. Sci. Technol. 46 (20), 10883-10891.

Sumper, A., Robledo-Garcia, M., Villafafila-Robles, R., Bergas-Jane, J., Andres-Peiro, J., 2011. Life-cycle assessment of a photovoltaic system in Catalonia (Spain). Renew. Sust. Energ. Rev. 15 (8), 3888-3896. http://dx.doi.org/10.1016/ j.rser.2011.07.023.

Van Oers, L., 2004. CML-IA-Database Containing Characterization Factors for Life Cycle Impact Assessment. Centre of Environmental Science (CML) Leiden, The Netherlands. http://www.leidenunivnl/interfac/cml/ssp/index.html.

Wu, F.Z., Jin, H.X., 2010. Analysis of energy consumption and directions and measures of conservation energy in metallurgical silicon production. Ind. Furn. (in Chinese) 32 (6), 27-30.

Ye, H.L., Ma, W.H., Yang, B., Ren, J.Y., Liu, D.C., Dai, Y.N., 2007. LCA study of metallurgical silicon process. Light Metals (in Chinese) 11, 46-49.

Yunfeng, Y., Laike, Y., 2010. China's foreign trade and climate change: a case study of $\mathrm{CO}_{2}$ emissions. Energy Policy 38 (1), 350-356.

Zhang, D., Tang, S., Lin, B., Liu, Z., Zhang, X., Zhang, D., 2012. Co-benefit of polycrystalline large-scale photovoltaic power in China. Energy 41 (1), 436-442. http://dx.doi.org/10.1016/j.energy.2012.02.056.

Zhang, S., He, Y., 2013. Analysis on the development and policy of solar PV power in China. Renew. Sustain. Energy Rev. 21 (0), 393-401. http://dx.doi.org/10.1016/j. rser.2013.01.002.

Zhong, Z.W., Song, B., Loh, R., 2011. LCAs of a polycrystalline photovoltaic module and a wind turbine. Renew. Energy 36 (8), 2227-2237. http://dx.doi.org/ 10.1016/j.renene.2011.01.021. 